\title{
The participation of methionine and cysteine in the formation of bonds resistant to the action of proteolytic enzymes in heated casein
}

\author{
By DANU'TA PIENIA̧ŹEK, MARIA RAKOWSKA AND \\ HANNA KUNACHOWICZ \\ Institute of Food and Nutrition, Warszawa, Powsiniska \\ 61/63, Poland \\ (Received ${ }_{4}$ December 1973-Accepted 21 March 1975)
}

\begin{abstract}
I. The influence of temperature, moisture content and the presence of glucose on the level of available methionine and cysteine in casein was studied.

2. Differences between total and available methionine and cysteine contents of heated casein ( $90^{\circ}$ for $24 \mathrm{~h}$ ) were determined by an in vitro method. The maximum losses in total and available methionine content were 22 and $51 \%$ respectively. The losses in total and available cysteine content were 24 and $100 \%$ respectively.

3. The results indicated that for heated casein the release of amino acids by proteolytic enzymes was less complete than for native casein.

4. The results of rat growth assays suggested that diets containing oxidized casein are less well utilized by rats than those containing native casein. The decrease in body-weight of rats receiving the diets containing oxidized casein could be counteracted by the addition of methionine and $20 \mathrm{~g}$ unoxidized casein $/ \mathrm{kg}$ diet.

5. There was a lower level of some available amino acids (determined after enzymic hydrolysis using pancreatopeptidase $\mathrm{E}\left(E C \mathrm{~B}_{3.4 .4 .7}\right)$, leucine aminopeptidase $\left(E C C_{3.4 .1 .1}\right)$ and prolidase $\left.\left(E C C_{3} \cdot 4 \cdot 3 \cdot 7\right)\right)$, including those essential for the rat, in oxidized casein as compared with native casein.

6. Cysteic acid, in oxidized casein, probably makes impossible the utilization of the amino acids in its neighbourhood.

7. From the differences in the available amino acid contents of the native, oxidized and heated casein it was concluded that the oxidation of casein causes the formation of complexes in the polypeptide chain, resistant to enzymic hydrolysis, but to a much lesser extent than does heating.
\end{abstract}

The effects of high temperatures and the presence of reducing sugars during processing are the most common reasons for the reduction in the biological value of proteins of food products. This reduction is only to a small extent correlated with destruction of amino acids, and is mainly the result of a decrease in the available amino acid content associated with the formation of polypeptide fragments resistant to the action of proteolytic enzymes (Miller, Hartley \& Thomas, 1965).

The changes which occur in proteins as a result of technological processing are generally measured by methods based on changes in available lysine content, as this amino acid is very easy to determine both chemically and biologically.

It is known that the decrease in available lysine in proteins subjected to thermal processing is due to the blocking of $\epsilon$-amino groups, which occurs both in the presence and absence of reducing sugars, although the mechanism in the latter instance is not known.

Some workers have suggested that in the absence of carbonyl components character- 
istic of the Maillard reaction, the formation of glutamyl-lysine or aspartyl-lysine in drastically heated proteins could explain the decrease in biological value (Bjarnason \& Carpenter, 1969, 1970).

However, Waibel \& Carpenter (1972) have reported that these types of bonds are hydrolysed by proteolytic enzymes and the liberated lysine can be utilized by the organism. Thus reactions of this type cannot be responsible for the decrease in the available lysine content and, as a consequence, the biological value of the protein. Although the available amino acid content can be determined microbiologically, this method cannot be used to study the mechanism of changes occurring in the other amino acids in proteins, which lead to a decrease in biological value.

Therefore because of procedural difficulties little is known about the effects of processing on the formation, in proteins, of forms of amino acids which are not available to the organism, e.g. methionine sulphone or cysteic acid ( $\mathrm{Njaa}$, 1962; Carpenter \& Bjarnason, 1968) and the participation of amino acids other than lysine in the formation of polypeptide fragments resistant to the action of proteolytic enzymes.

In the present work both in vivo and in vitro experiments were done to study the effects of the presence of oxidized forms of sulphur amino acids (methionine sulphone and cysteic acid) in casein on the liberation of amino acids, and how methionine and cysteine in casein subjected to high temperatures participate in the formation of bonds resistant to hydrolysis by proteolytic enzymes.

\section{EXPERIMENTAL}

\section{Materials and methods}

Casein (BDH Ltd, Poole, Dorset) was oxidized by the performic acid method of Toennies (1942). Air-dried casein and casein containing $800 \mathrm{mg}$ moisture/g were heated in an oven at $90^{\circ}$ for $24 \mathrm{~h}$ in the presence or absence of D-glucose $\left(5^{\circ} \mathrm{mg} / \mathrm{g}\right.$ casein).

Enzymic hydrolysis of casein using pancreatopeptidase $E(E C$ 3.4.4.7) (K \& K Laboratories Inc., California, USA) was done by the method of Pieniążek, Rakowska, Szkilłądziowa \& Grabarek (1975). After $24 \mathrm{~h}$ hydrolysis the $\mathrm{pH}$ of the hydrolysate was adjusted to $2 \cdot 0$ using $\mathrm{I} \mathrm{M}-\mathrm{HCl}$ and the sample was evaporated to dryness; $5 \mathrm{ml}$ $0.05 \mathrm{M}-\mathrm{Tris}-\mathrm{HCl}\left(\mathrm{pH} \mathrm{8.5)}, 0 . \mathrm{I} \mathrm{ml}\right.$ toluene, $0.1 \mathrm{ml} 0.04 \mathrm{M}-\mathrm{MnSO}_{4}$ and $0.2 \mathrm{ml}$ leucine aminopeptidase ( $E C$ 3 . 4. I . I) (Sigma Chemical Corp., St Louis, Missouri, USA) and $0.1 \mathrm{ml}$ of a solution containing $10 \mathrm{mg}$ prolidase $\left(E C C_{3.4 .3 .7}\right)$ (isolated from pig kidney by the method of Smith (1955))/ml, were added and the mixture was incubated at $40^{\circ}$ for $24 \mathrm{~h}$ with continuous shaking. After hydrolysis, the samples were desalted using Dowex $50 \mathrm{~W} \times 8$ (Serva Feinbiochemica, Heidelberg, Germany).

The available methionine and cysteine contents of casein were determined by the in vitro method of Pieniąźek et al. (1975).

The total amino acid content of casein was determined by the acid-hydrolysis method of Moore, Spackman \& Stein (1958). The amino acid contents of enzymic hydrolysates and acid-hydrolysates were estimated using an amino acid analyser (TSM; Technicon Instruments Corporation, Tarry Town, New York, USA). 
Table I. Composition ( $\mathrm{g} / \mathrm{kg}$ ) of diets containing $\mathrm{I} 10$ or $\mathrm{I} 80 \mathrm{~g}$ protein $/ \mathrm{kg}$, with casein or oxidized casein as the sole source of protein, for rats

\begin{tabular}{|c|c|c|c|c|c|c|c|c|}
\hline \multirow[b]{2}{*}{ Ingredients } & \multicolumn{8}{|c|}{ Diet§ } \\
\hline & $D_{I}$ & $D^{\prime} I$ & $\mathrm{D}_{2}$ & $D_{2}^{\prime}$ & $\mathrm{D}_{3}$ & $\mathrm{D}_{3}^{\prime}$ & $\mathrm{D}_{4}$ & $\mathrm{D}_{5}$ \\
\hline Casein & 140 & 230 & - & - & - & - & 20 & 20 \\
\hline Oxidized casein & - & - & I 40 & 230 & 140 & 230 & 120 & 120 \\
\hline Wheat starch & $416 \cdot 5$ & 327 & 406 & 316 & 402 & 310 & 406 & 403 \\
\hline Potato starch & 50 & $5^{\circ}$ & 50 & 50 & 50 & 50 & 50 & 50 \\
\hline Sucrose & 200 & 200 & 200 & 200 & 200 & 200 & 200 & 200 \\
\hline Soya-bean oil & 120 & 120 & 120 & 120 & 120 & 120 & 120 & I2O \\
\hline Cod-1iver oil & 20 & 20 & 20 & 20 & 20 & 20 & 20 & 20 \\
\hline Mineral salts* & 40 & 40 & 40 & 40 & 40 & 40 & 40 & 40 \\
\hline $\begin{array}{l}\text { Vitamin B supple- } \\
\text { ment } \dagger\end{array}$ & ro & IO & 10 & 10 & Io & Io & I0 & IO \\
\hline \multicolumn{9}{|c|}{ Amino acid supplementsf: } \\
\hline L-methionine & - & - & - & - & $3 \cdot 5$ & $5 \cdot 7$ & - & $3 \cdot 0$ \\
\hline L-cysteine & 3.5 & $3 \cdot 2$ & $4 \cdot 0$ & $4 \cdot 0$ & 4.0 & 4.0 & $4 \cdot 0$ & $4^{\circ} \mathrm{O}$ \\
\hline L-tyrosine & - & - & $8 \cdot 0$ & $8 \cdot 0$ & $8 \cdot 0$ & $8 \cdot 0$ & $8 \cdot 0$ & $8 \cdot 0$ \\
\hline L-tryptophan & - & - & $2 \cdot 0$ & $2 \cdot 0$ & $2 \cdot 0$ & $2 \cdot 0$ & $2 \cdot 0$ & $2 \cdot 0$ \\
\hline $\begin{array}{l}\text { Energy } \\
\qquad(\mathrm{MJ}(\mathrm{Mcal}) / \mathrm{kg} \text { diet })\end{array}$ & $16 \cdot 7(4)$ & $16.7(4)$ & $16 \cdot 7(4)$ & $16 \cdot 7(4)$ & $16 \cdot 7(4)$ & $16.7(4)$ & $16.7(4)$ & $16 \cdot 7(4)$ \\
\hline
\end{tabular}

\section{Rat assays}

Wistar rats, $25 \mathrm{~d}$ old, (from the Institute colony) were divided into groups of five and given diets containing I 10 or $180 \mathrm{~g}$ protein $/ \mathrm{kg}$, with casein or oxidized casein as the sole protein source, for I I or $14 \mathrm{~d}$. The compositions of the diets are shown in Table I.

Diets $\mathrm{D}_{2}-\mathrm{D}_{5}$ and $\mathrm{D}_{2} \mathbf{2}_{2}-\mathrm{D}_{3}{ }_{3}$ were supplemented with tryptophan, tyrosine and cysteine (Schweigert \& Guthneck, 1954) and diets $\mathrm{D}_{3}-\mathrm{D}_{5}$ and $\mathrm{D}_{3}{ }_{3}$ were supplemented with methionine, because oxidation of casein is associated with the complete destruction of tryptophan, the partial destruction of tyrosine, and the conversion of cysteine to cysteic acid and methionine to methionine sulphone, neither of which is utilized by the organism (Miller \& Samuel, 1968; Ellinger \& Palmer, 1969).

The methionine supplement was equivalent to the methionine content of diets Dr and $\mathrm{D}^{\prime} \mathrm{x}$ respectively. Food intake and growth rate were recorded after Ir or I4 $\mathrm{d}$.

\section{RESULTS}

Effects of temperature, moisture content and the presence of glucose on the available and total methionine and cysteine contents of casein

The available methionine and cysteine contents of casein with various moisture contents heated $\left(90^{\circ}\right.$ for $\left.24 \mathrm{~h}\right)$ in the presence or absence of D-glucose were determined after enzymic hydrolysis of the casein using pancreatopeptidase E (Pieniąźek 


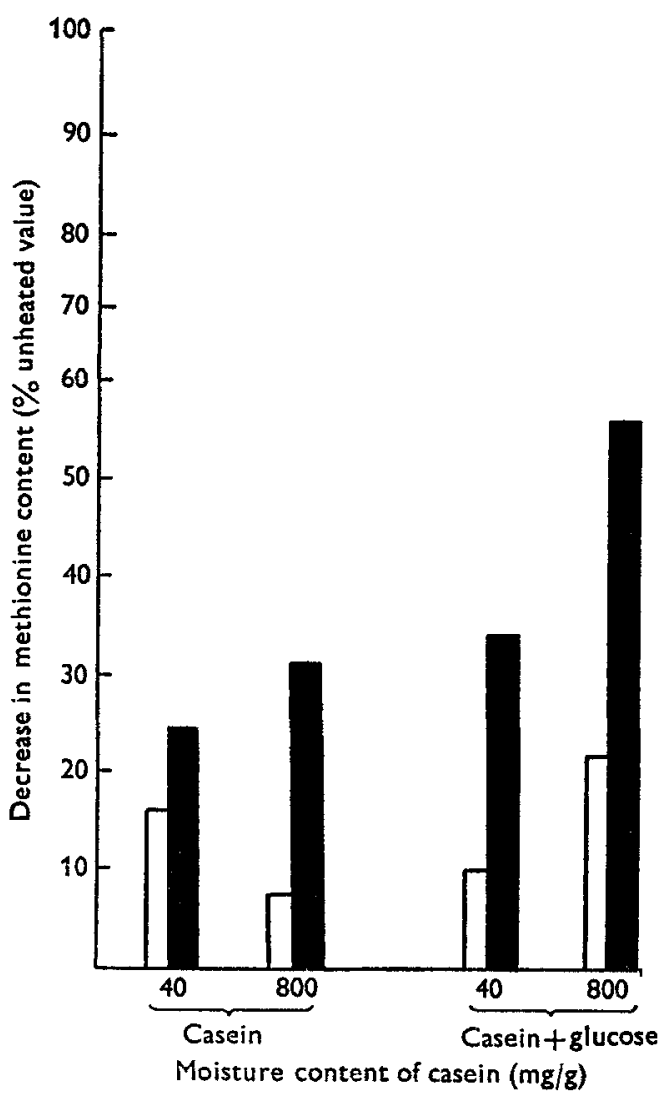

Fig. I

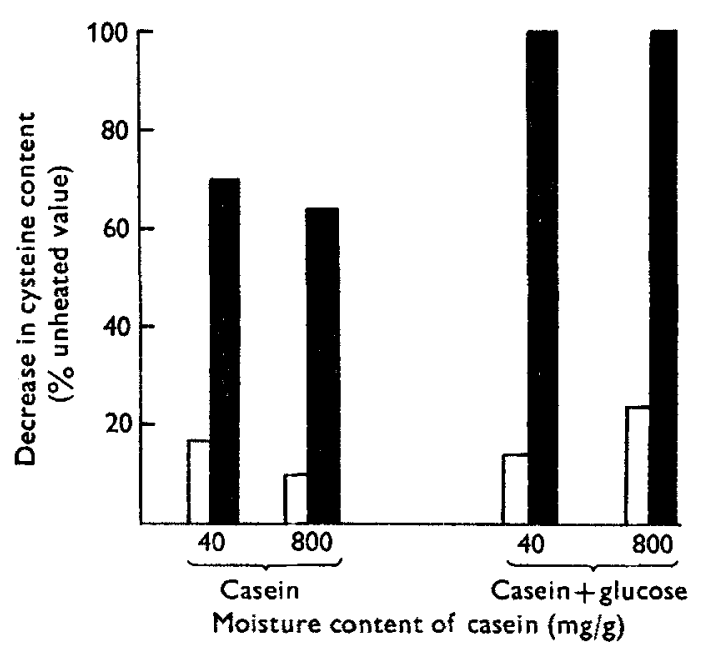

Fig. 2

Fig. I. The effect of D-glucose and moisture content on the total ( $\square$ ) and available ( $(\square)$ methionine contents of casein heated at $90^{\circ}$ for $24 \mathrm{~h}$. Casein containing 40 or $800 \mathrm{mg}$ moisture $/ \mathrm{g}$ was heated in the presence or absence of $50 \mathrm{mg} \mathrm{D}$-glucose $/ \mathrm{g}$ casein. Total and available methionine contents were determined after acid-hydrolysis (Moore, Spackman \& Stein, I958) and by the in vitro method of Pieniąźek, Rakowska, Szkiłłądziowa \& Grabarek (1975) respectively.

Fig. 2. The effect of D-glucose and moisture content on the total ( $\square$ ) and available ( $\square$ ) cysteine contents of casein heated at $90^{\circ}$ for $24 \mathrm{~h}$. Casein containing 40 or $800 \mathrm{mg}$ moisture/g was heated in the presence or absence of $50 \mathrm{mg}$ D-glucose/g casein. Total and available cysteine contents were determined after acid-hydrolysis (Moore, Spackman \& Stein, 1958) and by the in vitro method of Pienia̧źek, Rakowska, Szkiłłądziowa \& Grabarek (1975) respectively.

et al. 1975), and the total methionine and cysteine contents were estimated by the method of Moore et al. (1958).

There was a reduction in the amounts of available and total methionine and cysteine (Figs. I and 2).

The total methionine content of heated casein ranged from 8 to $22 \%$ of the value for unheated casein, with the greatest reduction occurring when casein containing $800 \mathrm{mg}$ moisture/g was heated in the presence of glucose. Values for available methionine content ranged from 24 to $5 \mathrm{I} \%$ of the value for unheated casein, and both moisture and glucose caused a reduction in the available methionine content.

The total cysteine content decreased by $10-24 \%$ when casein was heated and, as 
Table 2. The total amino acid content of unheated casein, and of casein with different moisture contents, heated at $90^{\circ}$ for $24 \mathrm{~h}$ in the presence or absence of D-glucose $(50 \mathrm{mg} / \mathrm{g}$ casein), determined after acid-hydrolysis*

(Mean values for two determinations)

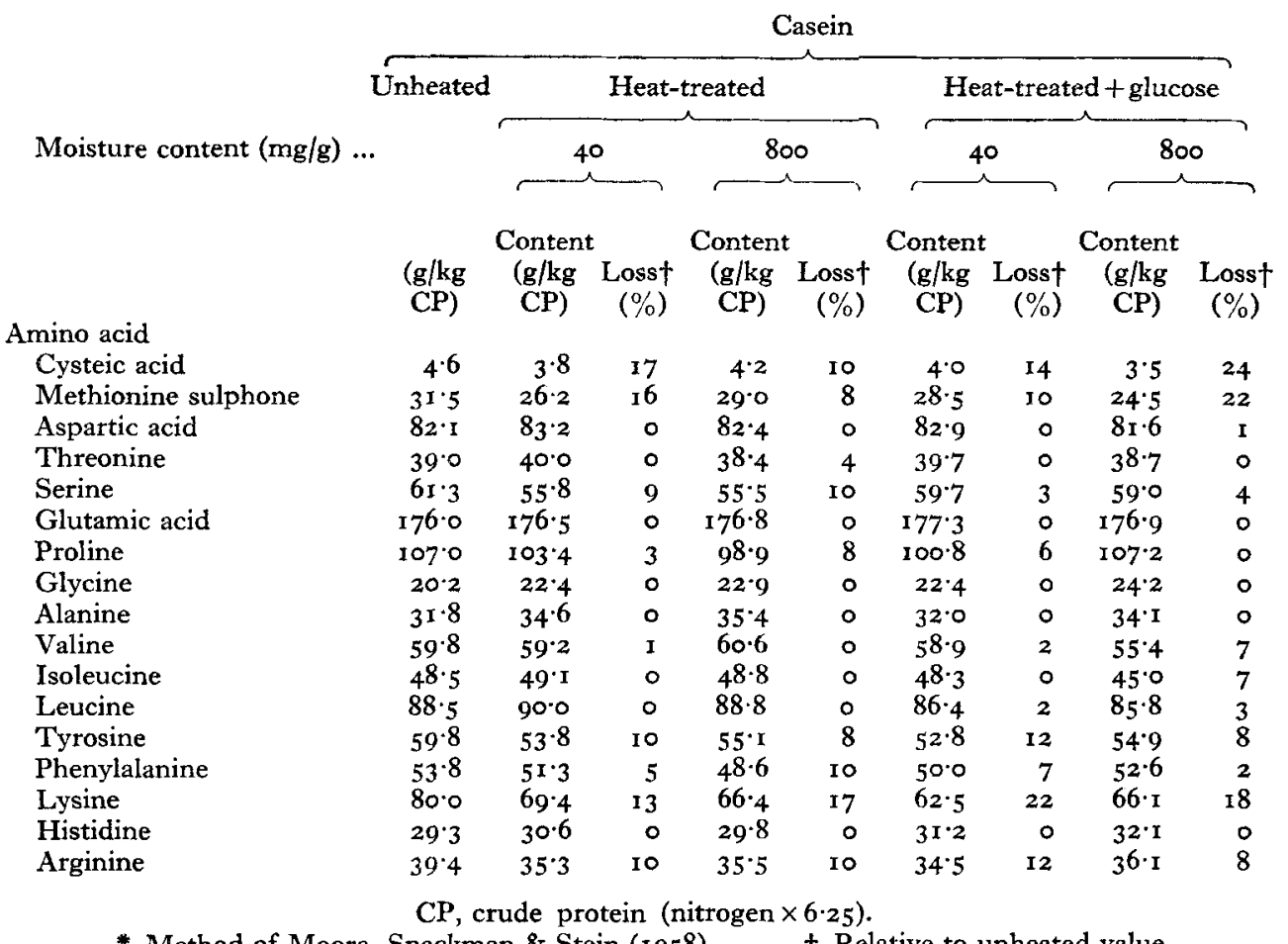

for methionine, the total cysteine content was affected by moisture and glucose and the effect was greatest when casein containing $800 \mathrm{mg}$ moisture/g was heated in the presence of glucose ( $24 \%$ reduction). The reduction in the available cysteine content was very high $(64-100 \%)$ and although moisture content did not affect the cysteine content, glucose caused a marked decrease.

Differences between the total and available methionine and cysteine contents of casein were not caused by the lowering of the total values in the sample during enzymic hydrolysis, since the recovery of nitrogen was $96-98 \%$.

To study changes which could occur in the amino acid composition of casein as a result of heating, and which could cause some differences between the total and available $\mathrm{S}$ amino acid contents, the amino acid compositions of the test samples were determined after acid-hydrolysis, and after enzymic hydrolysis procedures using pancreatopeptidase E, leucine aminopeptidase and prolidase. The results are shown in Tables 2 and 3 . There was a slight decrease in the total amount of some amino acids when casein was heated, and moisture content and glucose affected only the $\mathrm{S}$ amino acid contents, which were lowest in casein containing $800 \mathrm{mg}$ moisture/g heated at 
Table 3. The available amino acid content of unheated casein, and of casein with different moisture contents heated at $90^{\circ}$ for $24 \mathrm{~h}$ in the presence or absence of D-glucose $\left(5^{\circ} \mathrm{mg} / \mathrm{g}\right.$

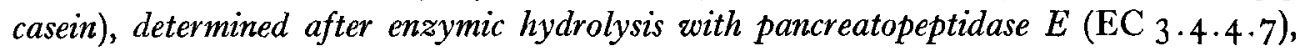
leucine aminopeptidase $\left(\mathrm{EC}_{3} \cdot 4 \cdot 4 \cdot \mathrm{I}\right)$ and prolidase $\left(\mathrm{EC}_{3} \cdot 4 \cdot 3 \cdot 7\right)$

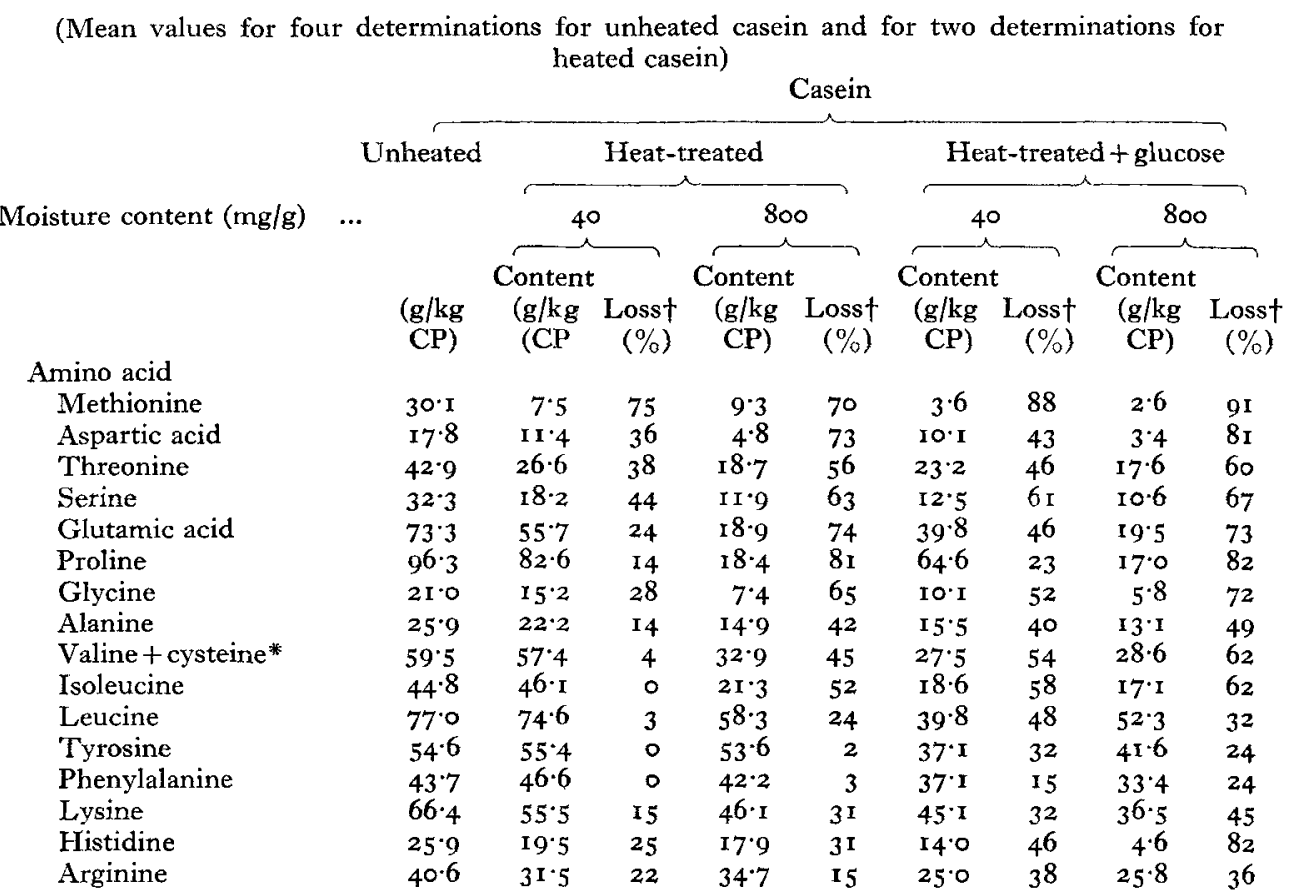

$\mathrm{CP}$, crude protein (nitrogen $\times 6 \cdot 25$ ).

* Cysteine was not determined as it co-chromatographed with valine.

$\dagger$ Relative to unheated value.

$90^{\circ}$ in the presence of D-glucose. Higher levels of some amino acids (glycine, alanine and histidine) were found for heated casein.

There was a significant decrease in the amino acid content (determined after enzymic hydrolysis) when casein containing $40 \mathrm{mg}$ moisture/g was heated at $90^{\circ}$ for $24 \mathrm{~h}$. Valine, isoleucine, leucine, tyrosine and phenylalanine were exceptions and the levels of these amino acids were unchanged. The greatest decrease in amino acid content was found in samples containing $800 \mathrm{mg}$ moisture/g, heated in the presence of D-glucose.

On heating there was a $75 \%$ decrease in the methionine content of casein containing $40 \mathrm{mg}$ moisture/g, but no further reduction was found when the moisture content was increased, although heating in the presence of glucose produced an $88 \%$ reduction. The greatest decrease $(91 \%)$ was found in the casein with $800 \mathrm{mg}$ moisture/g, heated in the presence of D-glucose. 
Table 4. Body-wt gain for rats fed for I I $d$ on diets containing I Io $g$ protein $/ \mathrm{kg}$, with casein $\left(\mathrm{D}_{1}\right)$, oxidized casein $\left(\mathrm{D}_{2}\right)$ or oxidized casein + methionine $\left(\mathrm{D}_{3}\right)$ as the sole source of protein

(Mean values for five rats/group)

\begin{tabular}{|c|c|c|}
\hline \multirow[b]{2}{*}{ Diet* } & \multicolumn{2}{|c|}{ Body-wt gain } \\
\hline & $\mathrm{g} /$ rat per I I $\mathrm{d}$ & $\% \mathrm{D}_{\mathrm{I}}$ value \\
\hline$D_{I}$ & +20 & 100 \\
\hline D2 & -12 & -60 \\
\hline $\mathrm{D}_{3}$ & +6 & 30 \\
\hline
\end{tabular}

Table 5. Body-wt gain, food intake and food conversion efficiency for rats fed for i $d$ on diets containing $180 \mathrm{~g}$ protein $/ \mathrm{kg}$, with casein $\left(\mathrm{D}^{\prime} \mathrm{I}\right.$, control), oxidized casein (D'2) or oxidized casein + methionine $\left(\mathrm{D}_{3}^{\prime}\right)$ as the sole source of protein

(Mean values for five rats/group)

\begin{tabular}{|c|c|c|c|c|c|}
\hline \multirow[b]{2}{*}{ Diet* } & \multicolumn{2}{|c|}{ Body-wt gain } & \multirow{2}{*}{$\begin{array}{c}\text { Food intake } \\
\text { (g DM/rat } \\
\text { per I I d) }\end{array}$} & \multicolumn{2}{|c|}{ Food conversion efficiency } \\
\hline & $\begin{array}{c}\mathrm{g} / \mathrm{rat} \\
\text { per I I } \mathrm{d}\end{array}$ & $\begin{array}{l}\% D^{\prime} 1 \\
\text { value }\end{array}$ & & $\begin{array}{l}g \text { body-wt gain/ } \\
\mathrm{g} \text { food intake }\end{array}$ & $\begin{array}{c}\% D_{1}^{\prime} \\
\text { value }\end{array}$ \\
\hline$D_{1}^{\prime}$ & +43 & 100 & $84 \cdot 6$ & 0.508 & 100 \\
\hline$D_{2}^{\prime}$ & -13 & -30 & $20 \cdot 6$ & -0.636 & -125 \\
\hline $\mathrm{D}_{3}^{\prime}$ & +14 & 32 & $4 \mathrm{I} \cdot 3$ & $0.34 I$ & +67 \\
\hline
\end{tabular}

The effect of methionine sulphone and cysteic acid in oxidized casein on its utilization by rats

The values for body-weight gain for rats (in the I I $d$ experimental period) given diets $D_{I}-D_{3}$ (casein, oxidized casein and oxidized casein + methionine respectively) and weight gain as a percentage of that for rats given diet DI are shown in Table 4. The weight gain for rats given diet $\mathrm{D}_{3}$ was only $30 \%$ of that for rats given diet $\mathrm{D}_{1}$.

To determine whether this low growth rate was associated with a toxic effect of the oxidized casein, the growth rate of rats fed on the same diets but with 180 g protein $/ \mathrm{kg}$ $\left(D^{\prime}{ }_{1}-D_{3}^{\prime}\right)$ was studied; the results obtained are shown in Table 5 .

The growth rate for rats given $\operatorname{diet} D_{3}^{\prime}$ was $32 \%$ of that for rats given diet $D^{\prime} I$ and the food conversion efficiency was $67 \%$ of that for rats given diet $D^{\prime}$ I. As growth rates obtained with diets containing I Io or I $80 \mathrm{~g}$ protein $/ \mathrm{kg}$ were similar, it was assumed that poorer growth of animals was not due to the toxic effect of oxidized casein, but to the amino acid deficiency in diets $D_{3}$ and $D_{3}^{\prime}$ which had the same amino acid content (determined after acid-hydrolysis).

When $20 \mathrm{~g}$ oxidized casein in diets $\mathrm{D}_{2}$ and $\mathrm{D}_{3}$ were replaced by $20 \mathrm{~g}$ casein (diets $\mathrm{D}_{4}$ and $\mathrm{D}_{5}$ respectively), the weight gain and food conversion efficiency for rats given diet $D_{5}$ were 76 and $93 \%$ respectively of that for rats given diet $D_{1}$ (Table 6). These 
Table 6. Body-wt gain, food intake and food conversion efficiency for rats fed for $\mathrm{I}_{4} d$ on diets containing I $10 \mathrm{~g}$ protein/kg, with casein ( $D_{\mathrm{I}}$, control), oxidized casein +casein $\left(D_{4}\right)$ or oxidized casein + casein + methionine $\left(D_{5}\right)$ as the sole source of protein

(Mean values for five rats/group)

\begin{tabular}{|c|c|c|c|c|c|}
\hline \multirow[b]{2}{*}{ Diet* } & \multicolumn{2}{|c|}{ Body-wt gain } & \multicolumn{3}{|c|}{ Food conversion efficiency } \\
\hline & $\begin{array}{c}\text { g/rat } \\
\text { per } \times 4 d\end{array}$ & $\begin{array}{l}\% \mathrm{Dr} \\
\text { value }\end{array}$ & $\begin{array}{l}\text { Food intake } \\
\text { (g DM/rat } \\
\text { per I4 d) }\end{array}$ & $\begin{array}{l}\mathrm{g} \text { body-wt gain/ } \\
\mathrm{g} \text { food intake }\end{array}$ & $\begin{array}{l}\% D_{I} \\
\text { value }\end{array}$ \\
\hline$D_{r}$ & +55 & 100 & 102.8 & 0.534 & 100 \\
\hline $\mathrm{D}_{4}$ & $-\mathbf{I} \mathbf{I}$ & -20 & $23: 3$ & -0.475 & -88 \\
\hline $\mathrm{D}_{5}$ & +34 & +76 & $69 \cdot 6$ & 0.489 & +93 \\
\hline
\end{tabular}

DM, dry matter.

* For details of diets, see Table I.

Table 7. Amino acid comtent ( $\mathrm{g} / \mathrm{kg}$ crude protein (nitrogen $\times 6 \cdot 25)$ ) of casein and oxidized casein determined after acid-hydrolysis* and enzymic hydrolysis with pancreatopeptidase $E\left(\mathrm{EC}_{3.4 .4 .7}\right.$ ), leucine aminopeptidase ( $\mathrm{EC}_{3} \cdot 4$. I . I) and prolidase (EC 3.4 . $3 \cdot 7)$

(Mean values for two determinations)

\begin{tabular}{|c|c|c|c|c|c|c|}
\hline \multirow[b]{2}{*}{ Amino acid } & \multicolumn{3}{|c|}{ After acid-hydrolysis } & \multicolumn{3}{|c|}{ After enzymic hydrolysis } \\
\hline & Casein & $\begin{array}{l}\text { Oxidized } \\
\text { casein }\end{array}$ & $\begin{array}{c}\text { Differ- } \\
\text { ence }(\%)\end{array}$ & Casein & $\begin{array}{l}\text { Oxidized } \\
\text { casein }\end{array}$ & $\begin{array}{c}\text { Differ- } \\
\text { ence }(\%)\end{array}$ \\
\hline Cysteic acid & $4 \cdot 5$ & $4 \cdot 4$ & 0 & - & 0 & - \\
\hline Methionine sulphone & $31 \cdot 5$ & 30.5 & 0 & 一 & $22 \cdot 4$ & 23 \\
\hline Methionine & - & - & - & $30 \cdot 1$ & - & - \\
\hline Aspartic acid & $82 \cdot 1$ & $80 \cdot 0$ & 3 & $27 \cdot 6$ & 16.6 & 7 \\
\hline Threonine & $39^{\circ} 0$ & $46 \cdot 5$ & o & $42 \cdot 9$ & $44 \cdot 0$ & 0 \\
\hline Serine & $6 x \cdot 3$ & $62 \cdot 3$ & 0 & $32 \cdot 3$ & $32 \cdot 8$ & 0 \\
\hline Glutamic acid & $176 \cdot 0$ & 168.0 & 6 & $73 \cdot 3$ & $80 \cdot 2$ & $\circ$ \\
\hline Proline & 1070 & $98 \cdot 5$ & 8 & $96 \cdot 3$ & $80 \cdot 0$ & 17 \\
\hline Glycine & $20 \cdot 2$ & $20 \cdot 4$ & o & $2 I \cdot 0$ & $17 \cdot 3$ & 18 \\
\hline Alanine & $3 \mathrm{I} \cdot 8$ & $3 I \cdot I$ & $\mathbf{I}$ & 25.9 & $26 \cdot 6$ & 0 \\
\hline Valine & $59 \cdot 8$ & $58 \cdot 6$ & 2 & $59 \cdot 5$ & $52 \cdot 5$ & I I \\
\hline Isoleucine & $48 \cdot 5$ & $45 \cdot 5$ & 4 & $44 \cdot 8$ & $41 \cdot 9$ & 6 \\
\hline Leucine & $88 \cdot 5$ & $88 \cdot 5$ & 0 & $77 \cdot 0$ & $66 \cdot 8$ & 13 \\
\hline Phenylalanine & $53 \cdot 8$ & $52 \cdot 0$ & 3 & 437 & $43 \cdot 9$ & 0 \\
\hline Histidine & $29 \cdot 3$ & $27 \cdot 4$ & 6 & $25^{\circ} 0$ & $23 \cdot 1$ & I I \\
\hline Arginine & 39.4 & $36 \cdot 5$ & 7 & $40 \cdot 6$ & 0 & 100 \\
\hline Tryptophan & 22.4 & - & 100 & $\dagger-$ & +- & - \\
\hline Tyrosine & $59 \cdot \dot{8}$ & $39^{\circ} 5$ & 34 & $54 \cdot 6$ & $34 \cdot 4$ & 37 \\
\hline Lysine & $80 \cdot 0$ & $79 \cdot 4$ & I & 66.0 & $66 \cdot 0$ & 0 \\
\hline
\end{tabular}

results suggested that the addition of $20 \mathrm{~g}$ casein $/ \mathrm{kg}$ to a diet containing oxidized casein and methionine $\left(\mathrm{D}_{5}\right)$ allowed growth at a level comparable to that of rats fed on the control casein diet (DI) and that the lower growth of rats given diet $\mathrm{D}_{3}$ (oxidized casein + methionine) compared with that for rats given diet $\mathrm{D}_{5}$ (oxidized casein + casein + methionine) was due to incomplete hydrolysis of oxidized casein by proteolytic 
enzymes in vivo. Therefore in vitro studies of the action of proteolytic enzymes on casein and oxidized casein were done.

The amino acid contents of casein and oxidized casein were determined after enzymic hydrolysis with pancreatopeptidase $\mathrm{E}$, leucine aminopeptidase and prolidase, and also after acid-hydrolysis as a control; the results are shown in Table 7 .

Oxidation of casein was associated with the total destruction of tryptophan and $34 \%$ loss of tyrosine (determined after acid-hydrolysis) while values obtained after enzymic hydrolysis suggested that oxidized casein was less well hydrolysed than casein in respect of the release of amino acids such as proline, glycine, valine, leucine, histidine and arginine; the latter occurred only in trace amounts. Values for the release of cysteic acid and methionine sulphone were 0 and $77 \%$ respectively. Of the amino acids mentioned, valine, leucine, histidine and arginine are essential to the rat. It was assumed therefore that the deficiency of these amino acids in diet $\mathrm{D}_{3}$ (oxidized casein + methionine) was the cause of the poor growth rate of the animals.

\section{DISCUSSION}

Differences were found in the available and total contents of methionine and cysteine for casein heated at $90^{\circ}$ for $24 \mathrm{~h}$. In a further stage of the study an attempt was made to interpret these differences. The amino acid composition of casein containing different moisture contents, heated in the presence and absence of D-glucose, was estimated after acid-hydrolysis (to obtain the total amino acid contents) or after enzymic hydrolysis (to determine the amounts of released forms of the amino acids). It was found that the total amino acid content was not significantly affected by moisture content or by the presence of glucose. Similar results were reported by Bjarnason \& Carpenter (1970) for heated bovine serum albumin, but they found no decrease in methionine content, although there was a $60 \%$ reduction in the cysteine content. Our results suggested that there was a decrease in both methionine and cysteine contents (Table 2), which in the latter instance was $17 \%$. It should be stressed, however, that different workers have reported different values for losses of cysteine depending on the type of protein passing through the technological processes (Ellinger \& Boyne, 1965; Miller et al. 1965). Increased levels of some amino acids have been reported by other workers (Dawson \& Woodham, 1966; Bjarnason \& Carpenter, 1970).

The use of pancreatopeptidase E, leucine aminopeptidase and prolidase for enzymic hydrolysis, as an optimal system for the liberation of amino acids in vitro, made possible a complete comparison of amino acid composition of heated and unheated casein.

A significant decrease was found in the amino acid content of casein on heating, and there was a further decrease in the presence of increased moisture and of glucose. The reduction in methionine content (Table 3) was $91 \%$ for casein containing $800 \mathrm{mg}$ moisture/g, heated in the presence of glucose.

When amino acid contents were determined after acid-hydrolysis, heating of casein resulted in a slight destruction of amino acids but there was a significant lowering of the amino acid contents of heated casein analysed after enzymic hydrolysis, suggesting 
that polypeptide fragments were formed which were resistant to the action of proteolytic enzymes.

It has been suggested that when high temperatures are applied to $\mathrm{S}$ amino acids they may be partly converted into their oxidized forms, which may result in the formation of peptide fragments resistant to enzymic digestion.

In the present work we found a lower growth rate for rats given a diet containing oxidized casein, compared to that for rats given the casein diet, although the total amino acid contents of the diets, as determined after acid-hydrolysis, were identical.

The use of enzymic hydrolysis (pancreatopeptidase E, leucine aminopeptidase and prolidase) to study the amino acid content of oxidized casein allowed this difference in the growth of rats to be interpreted. The concentrations of the available amino acids were found to be different for casein and oxidized casein; for oxidized casein the content of some essential amino acids, particularly arginine, was lower (Table 7 ). The reason for the lower growth rate of animals given the diet containing oxidized casein was presumably that the available amino acid contents were different. This was confirmed by the high food conversion efficiency obtained when $20 \mathrm{~g}$ oxidized casein $/ \mathrm{kg}$ diet was replaced by $20 \mathrm{~g}$ casein ( $93 \%$ of the value for the diet containing casein only).

The results of in vivo and in vitro studies have suggested that oxidation of casein not only causes the destruction of some amino acids (tryptophan, tyrosine) and the oxidation of $\mathrm{S}$ amino acids to forms (methionine sulphone and cysteic acid) not available to the organism, but also leads to the formation, in some fragments of polypeptide chain, of bonds resistant to the action of proteolytic enzymes, which in turn leads to a decrease in the concentration of available amino acids.

In the present work cysteic acid was not released from oxidized casein by proteases, and the available proline, glycine, valine, leucine, histidine and arginine contents of oxidized casein were lower than those for casein. These results are similar to those obtained by Wilkes, Bayliss \& Prescott (1973), who found that no amino acids were released from peptides in the neighbourhood of cysteic acid.

Oxidation of casein was found to be associated with the formation of complexes resistant to proteolytic enzymes but to a considerably lesser extent than for heated casein (see Tables 3 and 7), suggesting that the decrease in available amino acid contents for heated casein was not correlated only with the presence of cysteic acid in the polypeptide chain.

\section{REFERENCES}

Bjarnason, J. \& Carpenter, K. J. (I969). Br. F. Nutr. 23, 859.

Bjarnason, J. \& Carpenter, K. J. (1970). Br. F. Nutr. 24, 313.

Carpenter, K. J. \& Bjarnason, J. (r968). Proc. I.B.P. Symp., Stockholm p. $3 \times 9$.

Dawson, R. \& Woodham, A. A. (1966). Proc. Nutr. Soc. 25, ix.

Ellinger, G. M. \& Boyne, E. B. (1965). Br. F. Nutr. 19, 587.

Ellinger, G. M. \& Palmer, R. (1969). Proc. Nutr. Soc. 28, 42 A.

El-Maraghi, N. R. H., Platt, B. S. \& Stewart, R. J. C. (1965). Br. F. Nutr. r9, 49 I.

Hawk, P. B., Oser, B. L. \& Summerson, W. H. (1947). Practical Physiological Chemistry, p. 1163. Philadelphia: W. B. Saunders Co.

Kunachowicz, H. (1970). Investigation on net protein utilization cocfficient (NPU) in relation to the growth rate of experimental animals. PhD Thesis, Institute of Food and Nutrition, Warsaw, Poland.

Miller, D. S. \& Samuel, P. (1968). Proc. Nutr. Soc. 27, 21 A.

Miller, E. L., Hartley, A. W. \& Thomas, D. C. (1965). Br. F. Nutr. I9, 565. 
Moore, S., Spackman, D. H. \& Stein, W. H. (1958). Analyt. Chem. 30, I 185.

Njaa, L. R. (1962). Br. F. Nutr. 16, 571.

Pieniąźzek, D., Rakowska, M., Szkiłlądziowa, W. \& Grabarek, Z. (1975). Br. f. Nutr. 34, 175.

Schweigert, B. S. \& Guthneck, B. T. (r954). F. Nutr. 54, 333.

Smith, E. L. (1955). Meth. Enzym. 2, 93.

Toennies, G. (I942). F. bial. Chem. 145, 667.

Waibel, P. E. \& Carpenter, K. J. (1972). Br. Y. Nutr. 27, 509.

Wilkes, S. H., Bayliss, M. E. \& Prescott, J. M. (1973). Eur. F. Biochem. 34, 459. 